Viera Zatkaliková

Monika Oravcová

Peter Palček

Lenka Markovičová

https://doi.org/10.21278/TOF.41403

ISSN 1333-1124

eISSN 1849-1391

\title{
THE EFFECT OF SURFACE TREATMENT ON CORROSION RESISTANCE OF AUSTENITIC BIOMATERIAL
}

\begin{abstract}
Summary
This paper focuses on the effect of surface treatment (grinding, electrochemical polishing) on the corrosion resistance of AISI 316L, a Cr-Ni-Mo low-carbon austenitic surgical stainless steel, in a physiological solution at the temperature of $37^{\circ} \mathrm{C}$. The influence of a surface defect and of sensitization by heat treatment on the corrosion behaviour of electrochemically polished surface is also studied. The evaluation is based on the results of cyclic potentiodynamic polarization tests and on the microscopic observation of specimen surfaces after performed tests. The analysis of cyclic potentiodynamic curves showed the highest pitting corrosion resistance of electrochemically polished specimens regardless of the previous sensitization. The as-received specimen showed the highest susceptibility to pitting, which was microscopically confirmed. Based on the performed experiments we can conclude that electrochemical polishing is an efficient chemical surface treatment to increase the resistance of AISI $316 \mathrm{~L}$ to pitting corrosion; the resistance to pitting corrosion of electrochemically polished surface can by markedly decreased by the presence of mechanical defects; the as-received surface and the ground surface showed lower resistance to pitting corrosion than electrochemically polished ones; sensitization induced by heat treatment $\left(700^{\circ} \mathrm{C} / 10\right.$ hours) does not decrease resistance to pitting corrosion.
\end{abstract}

Key words: $\quad$ austenitic biomaterial, pitting corrosion, electrochemical polishing, sensitization

\section{Introduction}

Austenitic stainless steels are used for various biomedical applications (e.g. medical equipment, surgical tools, and fixation screws) because of their biocompatibility [1,2], high corrosion resistance, and appropriate mechanical properties $[3,4]$. Their excellent resistance to uniform corrosion is related to the passive oxide surface film. However, aggressive ions present in the environment (halides, namely chlorides and bromides) can cause a local breakdown of this protective film and enable the progression of local pitting corrosion $[3,4]$.

Resistance to pitting of stainless steels is affected by a number of internal (chemical composition, structure, and quality of surface) and external factors (concentration of 
aggressive ions, temperature, and $\mathrm{pH}$ ). The quality of the surface passive film is one of the most important factors of the corrosion behaviour of stainless steels [3, 4]. The passive film properties are strongly influenced by mechanical and chemical finishing processes. The type of mechanical treatment (grinding, blasting, polishing, etc.) affects the electrochemical and mechanical stability of the passive film and near surface layers by changing the surface reactivity and by altering the near-surface residual stress state [3-5]. Mechanical treatment is usually the first step which is followed by a chemical reaction. Chemical reactions with the steel vary with the character of reagents; they are also affected by the preceding mechanical treatment [5]. The surface roughness resulting from the finishing processes used can be an important factor in the subsequent corrosion behaviour. As a result, surface preparation operations can alter the resistance of steel to the initiation and propagation of pitting [6-9].

The process of electrochemical polishing is a conventional chemical surface finish of metals, which results in a high surface quality with high surface brightness (mirror finish), an increase in corrosion resistance and a decrease in surface roughness $[10,11,12]$. The electropolishing process removes a particular layer from the metal surface. A high quality passive oxide film is created on the surface during the polishing process. Corrosion resistance of electrochemically polished materials increases because the surface is smoother and resistant to contamination and bacteria. That is why this treatment is mainly used in food, chemical, petrochemical, pharmaceutical, and medical industries. Electrochemical polishing in medicine is used mainly to polish surgical and ophthalmic devices and instruments and also joint replacements, jaw implants, and stents used in cardiology [10, 11].

Sasaki and Burstein [7] addressed the relationship between the pitting potential $E_{p}$ and the surface treatment of stainless steels. They pointed out that $E_{p}$ is lower for rougher surfaces than for smoother ones; they also found that the number of metastable pits is lower on smoother surfaces. According to [7], the possibility of development of pits that can pass through the stage of a stable growth is higher in the deeper, less open sites than in shallower and more open ones. Burstein and Pistorius [9] indicated that the smoother surface of AISI 304 stainless steel reduced the incidence of metastable pitting substantially by reducing the number of sites capable of being activated into a metastable pit growth.

The AISI 316L steel is a Cr-Ni-Mo low-carbon austenitic surgical stainless steel. This paper focuses on the effect of surface treatment (grinding and electrochemical polishing) on the corrosion resistance of this stainless steel in a physiological solution at the temperature of $37^{\circ} \mathrm{C}$. The influence of sensitization on the corrosion behaviour of electrochemically polished surfaces is also studied. Evaluation of the corrosion resistance is based on the results of electrochemical cyclic potentiodynamic polarization tests and on the microscopic observation of specimen surfaces following electrochemical tests.

\section{Experimental material}

The stainless steel AISI 316L, with its chemical composition listed in Table 1, was used as an experimental material. The steel was purchased in a $1.5 \mathrm{~mm}$ thick sheet $(1000 \times 2000$ $\mathrm{mm}$ ) and its treatment (marked as $2 \mathrm{~B}$ ) was based on annealing and pickling after smoothing rolling.

Table 1 Chemical composition of experimental material

\begin{tabular}{|c|c|c|c|c|c|c|c|c|c|c|}
\hline $\begin{array}{c}\text { Content of } \\
\text { element } \\
\text { [wt.\%] }\end{array}$ & 16.79 & 10.14 & 2.03 & 0.82 & 0.05 & 0.02 & 0.31 & 0.03 & 0.001 & balance \\
\cline { 2 - 11 }
\end{tabular}


The microstructure of the experimental material (determined by a Neophot 32 optical metallographic microscope) in cross and longitudinal sections is shown in Fig. 1 and Fig. 2. It consists of polyedric austenitic grains with observable twins, which could be created by annealing or by rolling. Parallel lines visible in the longitudinal section (Fig. 2) were created by the rolling during the technological process. The $(\mathrm{Mo}, \mathrm{Cr})_{23} \mathrm{C}_{6}$ carbides [13] are localized along the above mentioned lines.
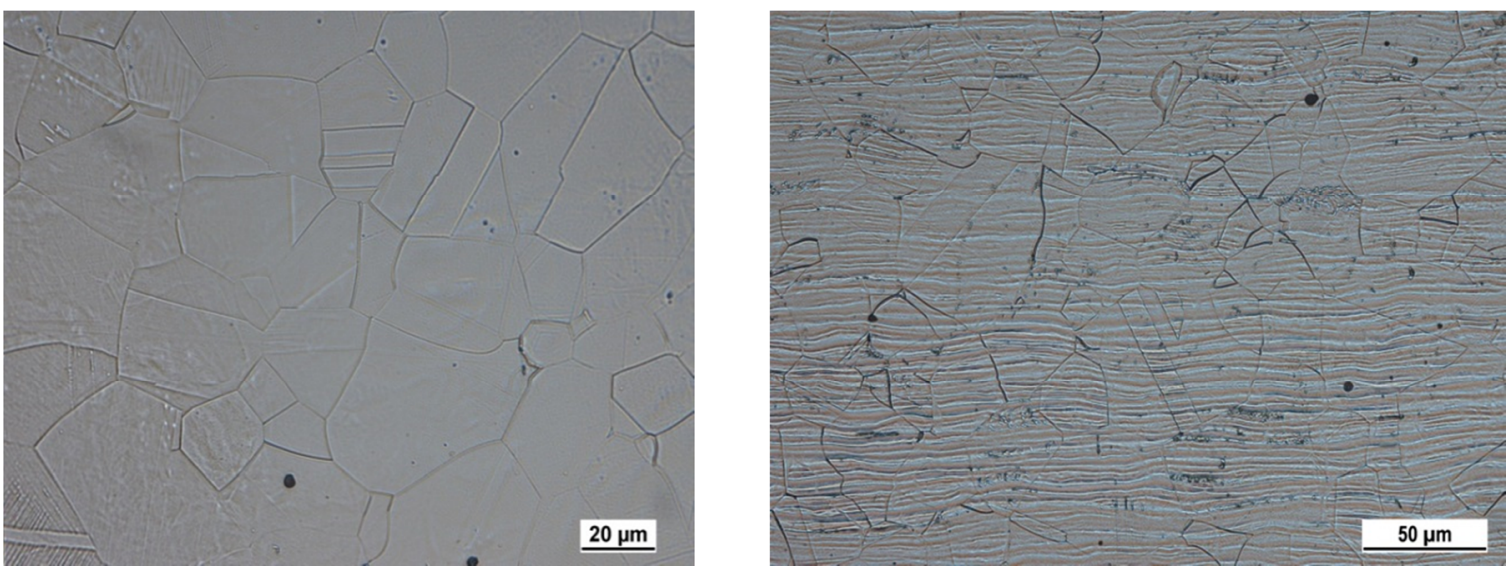

Fig. 1 Microstructure of AISI 316L stainless steel (Kalling's etch) in cross section (a) and in longitudinal section (b)

\section{Experimental conditions and methods}

For the simulation of internal conditions in the human body, all experiments were performed in a physiological solution represented by the $0.9 \% \mathrm{NaCl}$ solution (i.e. $0.15 \mathrm{M}$ $\mathrm{NaCl})$.

\subsection{Surface preparation}

Specimens of six various types of surfaces were tested:

1. as-received surface, i.e. surface without additional mechanical and chemical treatment;

2. electrochemically polished surface;

3. electrochemically polished surface with a surface defect (scratched surface which simulates mechanical damage to the implant inflicted by a surgical instrument);

4. electrochemically polished surface after sensitization of experimental material by heat treatment $\left(700{ }^{\circ} \mathrm{C} / 10\right.$ hours $)$;

5. electrochemically polished surface after sensitization of experimental material by heat treatment, with a surface defect;

6. ground surface (abrasive paper, grit size 500 and subsequently 1200).

Electrochemical polishing was performed in the $\mathrm{H}_{3} \mathrm{PO}_{4}+\mathrm{H}_{2} \mathrm{SO}_{4}+\mathrm{H}_{2} \mathrm{O}$ electrolyte under the conditions listed in Table 2 [10]. A polished specimen was immersed into the electrolyte and connected to the positive pole of the power source as an anode. A cathode was of the same material as the anode [10].

Table 2 Conditions of electrochemical polishing

\begin{tabular}{|c|c|c|c|c|}
\hline Component & Content [wt.\%] & Temperature $\left[{ }^{\circ} \mathrm{C}\right]$ & $\begin{array}{c}\text { Current density } \\
{\left[\mathrm{Acm}^{-2}\right]}\end{array}$ & Time $[\mathrm{s}]$ \\
\hline $\mathrm{H}_{3} \mathrm{PO}_{4}$ & 64 & 40 & 0.8 & 420 \\
$\mathrm{H}_{2} \mathrm{SO}_{4}$ & 13 & 43 & 0.8 & \\
$\mathrm{H}_{2} \mathrm{O}$ & 23 & & & \\
\hline
\end{tabular}




\subsection{Cyclic potentiodynamic polarization tests}

Cyclic potentiodynamic polarization tests were carried out in a three-electrode cell of the corrosion measuring system (VoltaLab 10 with VSP unit). Potentiodynamic polarization curves were obtained by the EC-LAB SOFT software. The potential between the specimen and the electrolyte had settled in 10 minutes before the polarization. The scan range was $-0.3 \mathrm{~V}-2.0 \mathrm{~V}$ with respect to the open circuit potential and the scan rate was $1 \mathrm{mV} / \mathrm{s}$. The surface of the AISI $316 \mathrm{~L}$ working electrode (the area of $1 \mathrm{~cm}^{2}$ ) was rinsed with ethanol before measurement $[4,14]$. The saturated calomel electrode (SCE) was applied as the reference electrode and platinum foil as a counter electrode. All experiments were carried out at the temperature of $37 \pm 0.5{ }^{\circ} \mathrm{C}$. At least five experiment repeats were carried out for all specimens.

\section{Experiment results}

Cyclic potentiodynamic polarization curves express dependence of the current density $i$ $\left[\mathrm{mAcm}^{-2}\right]$ on the potential $E[\mathrm{~V}]$. They enable the determination of the passivity region and the pitting potential $E_{p}$, which is an important electrochemical characteristic of the resistance to pitting. The pitting potential $E_{p}$ can be located as the potential of a sharp increase in the current density on the polarization curve of direct measurement [3,4]. When the potential reaches this critical value, the current density suddenly increases, denoting the breakdown of the passive film and the beginning of a stable pit growth. The shift of $E_{p}$ to more positive values on the polarization curve denotes the rise in stability to pitting [3,4]. Figure 2 shows cyclic curves of variously treated AISI $316 \mathrm{~L}$ stainless steel surfaces immersed in a physiological solution.

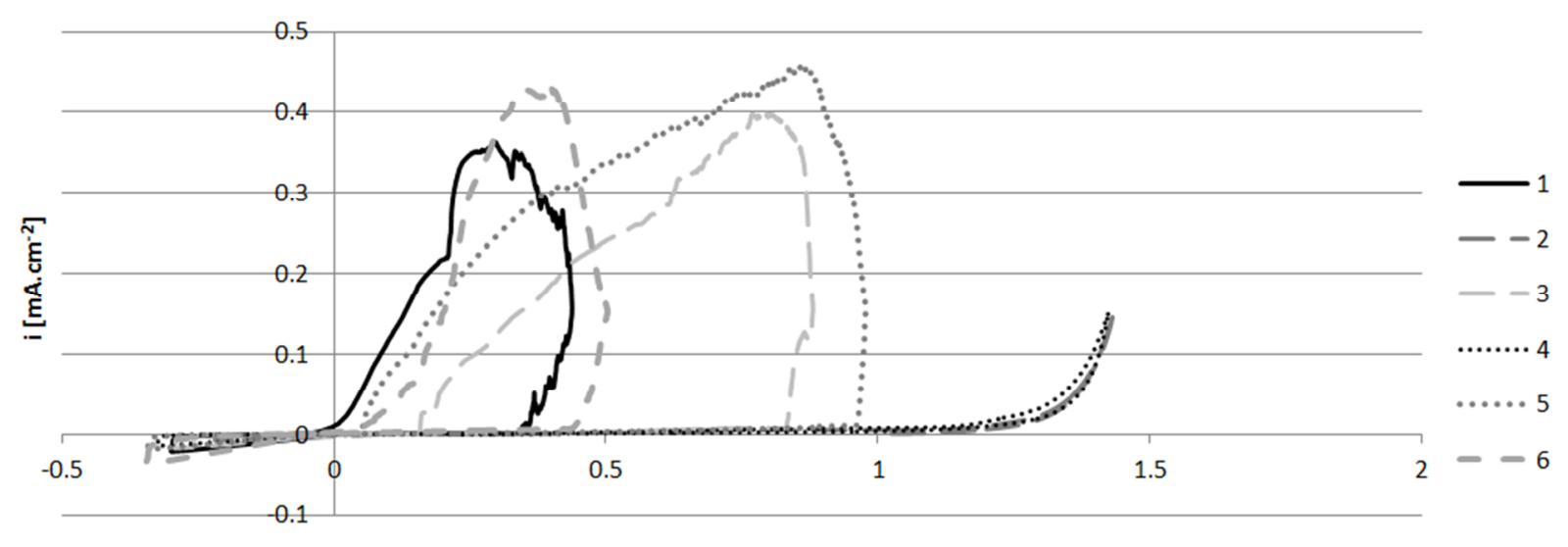

Ewe/V vs. SCE

Fig. 2 Potentiodynamic cyclic polarization curves of AISI 316L: 1. as-received surface; 2. electropolished surface; 3. electropolished surface with a surface defect; 4 . electropolished surface after sensitization; 5. electropolished surface after sensitization with a surface defect; 6 . ground surface

Curves 1, 3, 5, 6 (Fig. 2) are of a typical loop shape with a passivity region and a sharp increase in the current density at the pitting potential (Fig. 4). Passivity regions of electropolished specimens without surface defects (Fig. 3, curves 2 and 4) are very broad; no breakdown of passivity, which indicates the initiation of pitting corrosion, was recorded within them. The current density suddenly increases at a potential of approximately $1.2 \mathrm{~V}$ (Fig. 3), which can be considered as the trans-passivation potential $E_{t}$ [14]. If the potential is equal or higher than $E_{t}$, the surface passive film is dissolved and active corrosion of material starts $[3,4,14]$. This is also confirmed by the Pourbaix diagram for $\mathrm{Cr}$ (Fig. 4). 


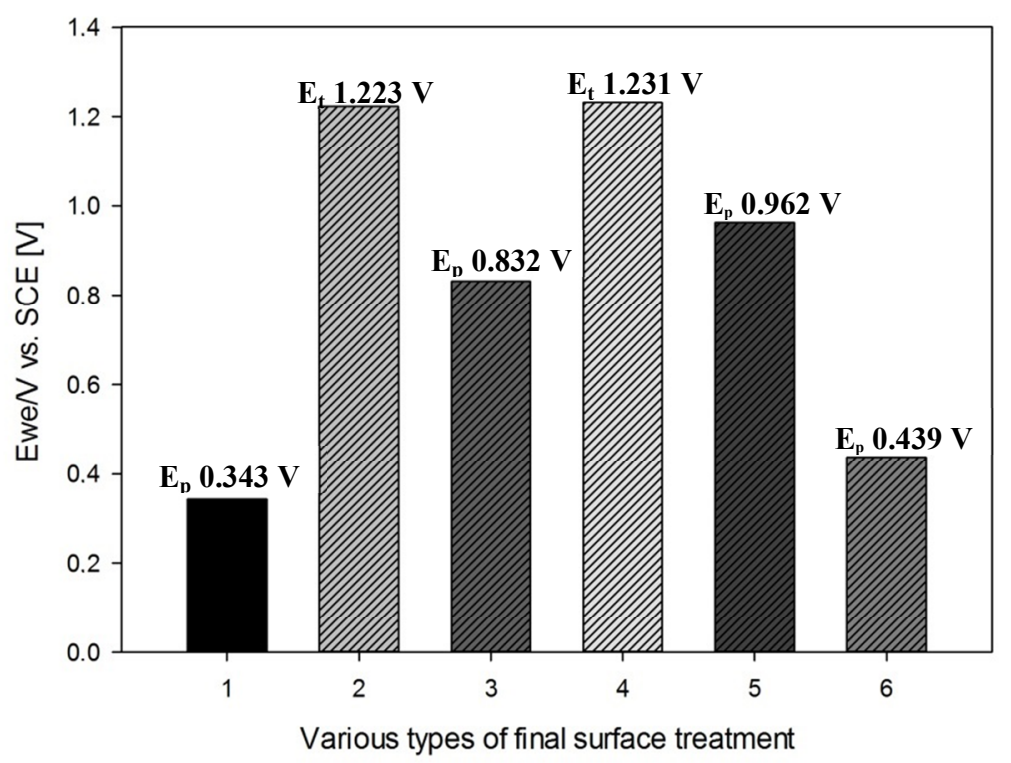

Fig. 3 Comparison of important potentials: 1. as-received surface; 2. electropolished surface; 3. electropolished surface with a surface defect; 4. electropolished surface after sensitization; 5. electropolished surface after sensitization with a surface defect; 6 . ground surface: $\left(E_{p}\right.$ - pitting potential, $E_{t}$ - trans-passivation potential $)$

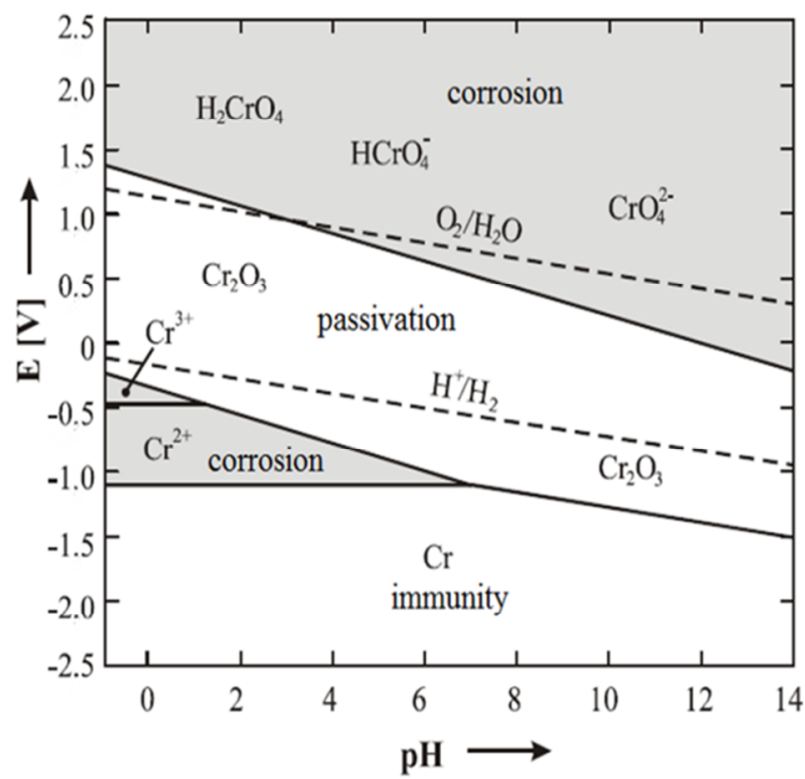

Fig. 4 Pourbaix diagram for $\mathrm{Cr}[14]$

Microstructures of AISI 316L after cyclic potentiodynamic polarization tests were observed by a NIKON AZ 100 optical microscope. The surface tested in the as- received state (Fig. 5), the electrochemically polished surface with a surface defect (Fig. 6), the surface electrochemically polished after sensitization, with a surface defect (Fig. 7), and the ground surface (Fig. 8) were all attacked by pitting corrosion.

After 7 minutes of electrochemical polishing in an electrolyte with the applied current density of $0.8 \mathrm{Acm}^{-2}$, a $0.08-0.09 \mathrm{~mm}$-thick layer was removed from the surface of the specimen. This amount of the removed material corresponds with the layer $(0.02 \mathrm{~mm})$ removed from the specimen after the electrolytic polishing carried out in [15]. 
The smoothness of the electropolished surface was observed macroscopically; in addition, the surface roughness of the polished and as-received surfaces was measured. Surface roughness is an arithmetic mean average stating the surface roughness parameters $\left(R_{a}\right.$ - roughness average, $R_{q}$ - root mean square roughness, $R_{z}$ - mean roughness depth) listed in Table 3. Surface roughness measurement was carried out by means of a portable Mitutoyo SJ210 tester in the standard measurement conditions: $4 \times 10^{-3} \mathrm{~N}$ measuring force, VDA=0.5 $\mathrm{mm} / \mathrm{s}$, and $\lambda_{\mathrm{c}}=0.8 \mathrm{~mm}$. The electropolished specimen shows a significant decrease in the average value of surface roughness in comparison with the as-received specimen.

Table 3 Average surface roughness parameters

\begin{tabular}{|l|l|l|l|}
\hline & $R_{a}[\mu \mathrm{m}]$ & $R_{q}[\mu \mathrm{m}]$ & $R_{z}[\mu \mathrm{m}]$ \\
\hline Electropolished surface & 0.078 & 0.096 & 0.474 \\
\hline "As received" surface & 0.256 & 0.363 & 2.290 \\
\hline
\end{tabular}

\section{Discussion}

A comparison of cyclic potentiodynamic curves (Fig. 2) shows that electropolished surfaces without mechanical defects (curves 2 and 4) have the highest resistance to pitting corrosion. Electrochemical polishing enabled the formation of a high quality $\mathrm{Cr}_{2} \mathrm{O}_{3}$ passive film, which protects the steel surface in the whole passive region $[11,15,16]$. Appropriate polishing current density is a very important parameter for effectual surface finish. The application of a high current density leads to a more intensive bubble formation, which can cause microscopic pits on the surface of the specimen [15]. The rise in the current density at the trans-passivation potential $E_{t}$ (about $1.2 \mathrm{~V}$ ) points to the beginning of $\mathrm{Cr}_{2} \mathrm{O}_{3}$ dissolution and the formation of soluble chromates (Fig. 4), which do not create a protective barrier between the metal and the electrolyte [3, 4, 14]. However, it should be noted that the active corrosion of the tested biomaterial in the trans-passive region in the internal environment of the human body is not an option because of a high $E_{t}$ value, which cannot be reached spontaneously under the given conditions.

Electropolishing did not reveal the sensitization of austenitic stainless steel which could be observed by almost the same course of the cyclic potentiodynamic curve (curve 4, Fig. 2) as of the curve 2 in the same figure. Sensitization of the experimental material during heat treatment is real; it was confirmed by microscopic observation (Figs. 9, 10, 11) after an electrolytic etching test in a $10 \%$ oxalic acid solution according to the standard [17]. The etching test was performed at the current density of $1 \mathrm{Acm}^{-2}$ for $90 \mathrm{~s}$. This etching test is used to detect carbide segregation at grain boundaries, the so-called sensitization, which can occur when a stainless steel is held at temperatures of $500-900{ }^{\circ} \mathrm{C}$ [17]. A sensitized material might become susceptible to intergranular corrosion if exposed to an aggressive corrosion environment $[3,4,13,14]$. The microstructure of the austenitic stainless steel AISI $316 \mathrm{~L}$ after being held at the temperature of $700{ }^{\circ} \mathrm{C}$ for 10 hours and electroetched in the oxalic acid is shown in Figs. 9 and 10, where grain boundaries are revealed because of the formation of chromium carbides. In Figure 11, which shows the microstructure of the same steel when observed by a light microscope using polarized light, we can also see grain boundaries. Based on the above mentioned, we can conclude that the cyclic potentiodynamic test performed under the given conditions was not appropriate to the task of revealing susceptibility to intergranular corrosion. 
By poor surface treatment, failure of the implanted material can occur due to the fatigue failure. This happens because the fatigue mechanism starts at sites with machining imperfections that act as stress concentrators. Failure of the implanted material can be caused by poor surface finishing as well as by inappropriate heat treatment that can cause sensitization of stainless steel which can escalate to the final failure. As could be observed, the surface of sensitized steel after electropolishing was highly resistant to pitting corrosion and there were no signs of sensitization. However, if this improperly treated steel was implanted instead of a hip joint and was subjected to cyclic loading, it might fail prematurely due to fatigue or due to a combination of corrosion and fatigue.

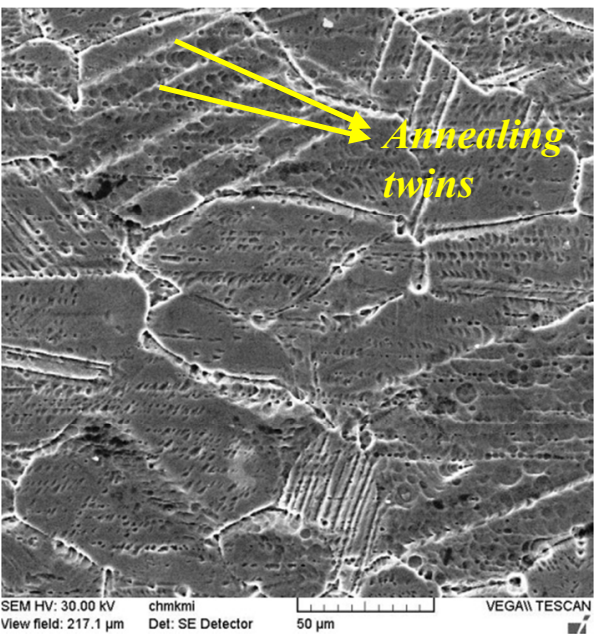

Fig. 5 Microstructure of AISI 316L after sensitization, $700{ }^{\circ} \mathrm{C} / 10$ hours, electroetched in oxalic acid, REM

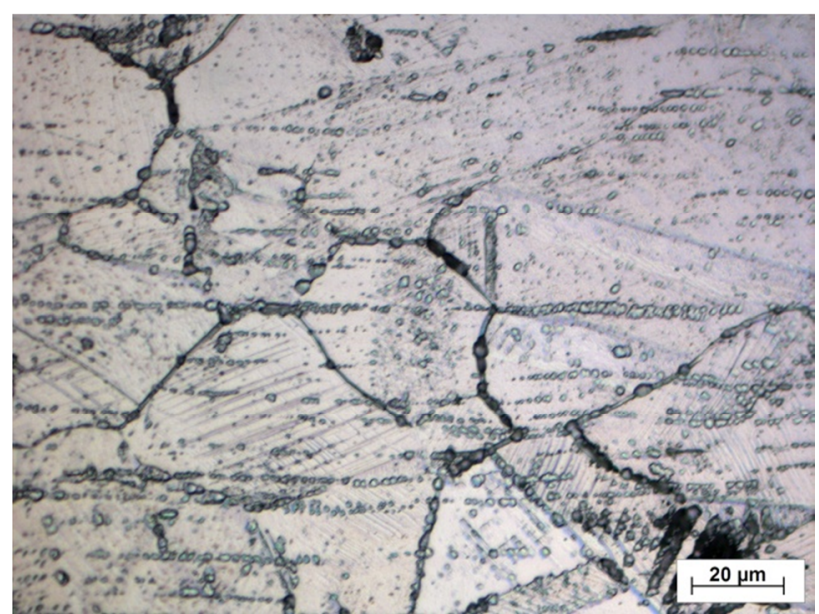

Fig. 6 Microstructure of AISI 316L after sensitization, $700{ }^{\circ} \mathrm{C} / 10$ hours, electroetched in oxalic acid, light microscopy

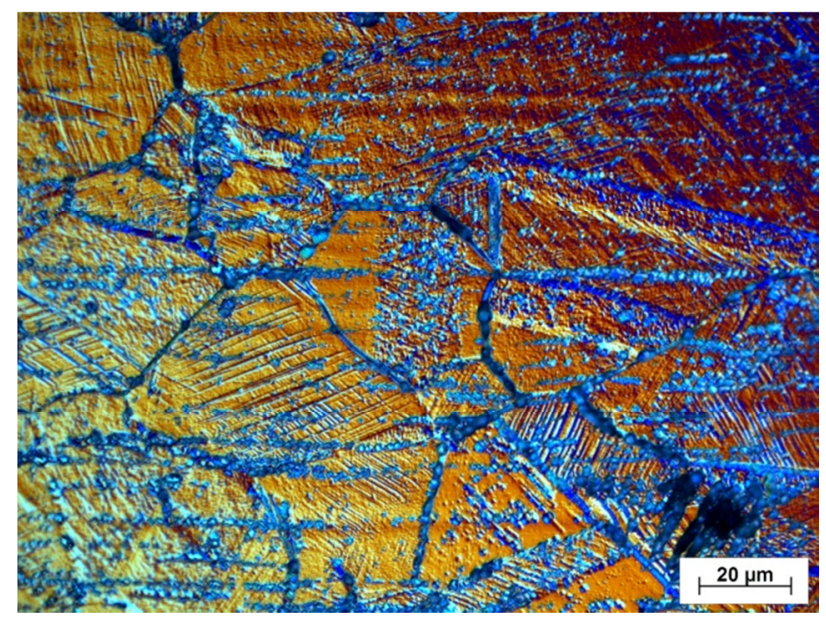

Fig. 7 Microstructure of AISI 316L after sensitization, $700{ }^{\circ} \mathrm{C} / 10$ hours, electroetched in oxalic acid, light microscopy, polarized light

If electrochemically polished specimens have surface defects, their corrosion behaviour differs from those with defect-free surfaces. This can be seen from the course of cyclic curves 3 and 5 (Fig. 2), which indicate the breakdown of the passive film at the respective pitting potentials and the initiation of pitting corrosion (Fig. 3). This form of corrosion attack was also reflected in the microstructures (Figs. 6 and 7). Corrosion pits on the surface of the specimen without sensitization are oblong and well bounded. No pit germs are visible in the 
area. On the surface of the sensitized specimen there is a round-shaped pit and a number of much smaller germs in its surroundings (Fig 7).

The as-received surface of the material proved to be the least resistant to pitting corrosion (Fig. 2 curve 1) because of its lowest pitting potential. Similarly, the specimen surface in Fig 5 shows oblong corrosion pits with irregular edges. In agreement with Fig. 2 (curve 5) and Figs. 3 and 8, resistance of the ground surface is slightly higher than that of the as-received surface.

The documented pitting corrosion damage indicates that nickel ions could be released from the biomaterial into the environment during exposure. Nickel ions are very harmful because they have allergenic, toxic and carcinogenic properties and can cause allergic contact dermatitis as well $[1,2,18]$. Therefore, the corrosion phenomenon not only affects the mechanical properties of metal appliances, but may also influence the body due to leached metal ions.

The toxicity and carcinogenicity of nickel are related to certain compounds containing nickel. In vivo, $\mathrm{Ni}^{2+}$ ions may cross cell membranes using the $\mathrm{Mg}^{2+}$ ion transport system, and then bind to cytoplasmic ligands, although the soluble $\mathrm{Ni}^{2+}$ is rapidly cleared. There is no specific mechanism for the delivery of $\mathrm{Ni}^{2+}$ to target sites in the cell nucleus that may result in genetic mutations causing cancer. The mechanism by which a nickel compound may be harmful is its active uptake by cells through their membranes. Harmful changes such as the formation of oxygen radicals and subsequent DNA damage can occur. It has been found that pure nickel implanted in the bone caused severe local tissue irritation and necrosis. Metal ions released due to the corrosion of the implanted steel can migrate into distant organs (liver, kidney, spleen), can accumulate there and have harmful effects [18].

Not only nickel but also other steel alloying elements can cause damage in the human body. Large amounts of iron released from metallic implants can increase the level of iron in the blood. High blood levels of free ferrous iron react with peroxides and produce free radicals, which are highly reactive and can damage the DNA, proteins, and lipids. Iron typically damages cells in the heart and the liver, which can cause significant adverse effects, including coma, liver failure, and other long-term organ damage [18].

\section{Conclusions}

Based on the experiments performed on the AISI 316L austenitic biomaterial, we can conclude:

- Electrochemical polishing carried out in the $\mathrm{H}_{3} \mathrm{PO}_{4}+\mathrm{H}_{2} \mathrm{SO}_{4}+\mathrm{H}_{2} \mathrm{O}$ electrolyte under the recommended conditions (Table 2) is an efficient chemical surface treatment to increase the resistance of AISI $316 \mathrm{~L}$ to pitting corrosion in a physiological solution at the temperature of $37{ }^{\circ} \mathrm{C}$. Electropolishing reduced the surface roughness of the specimen; the as-received surface had the average value of surface roughness $R_{a}=0.256 \mu \mathrm{m}$ and the electropolished surface reached the surface roughness $R_{a}=0.078 \mu \mathrm{m}$.

- Resistance of electrochemically polished surface to pitting corrosion can by markedly decreased by the presence of mechanical defects. Therefore, caution is advised when using sharp surgical instruments that could damage the polished surface of a biomaterial prepared for the application to the human body. 
- The as-received surface and the ground surface showed lower resistance to pitting corrosion than electrochemically polished ones. Therefore, the non-treated and the ground surfaces are not recommended for the internal environment of the human body.

- Sensitization induced by heat treatment $\left(700{ }^{\circ} \mathrm{C} / 10\right.$ hours $)$ does not decrease resistance to pitting corrosion. However, in aggressive chloride solutions, sensitization may cause intergranular corrosion which may lead to lower fatigue resistance of the tested biomaterial.

\section{Acknowledgement}

The research was supported partially by the Scientific Grant Agency of the Ministry of Education, Science and Sport of the Slovak Republic, by the Slovak Academy of Science grant VEGA No. 1/0683/15, and by the project KEGA No. 044ŽU-4/2017.

\section{REFERENCES}

[1] Nagase, M. Host Reactions to Particulate Biomaterials. Encyclopedic handbook of biomaterials and bioengineering 1995, Vol. 1, Part A, New York.

[2] Ratner, B.D.; Hoffmann, A.S.; Schoen, F.J.; Lemons J.E. Biomaterials Science 2004, Elsevier, San Diego, USA.

[3] Szklarska-Smialowska, Z. Pitting and crevice corrosion 2005, Houston, Nace, 590.

[4] Liptáková, T. Bodová korózia nehrdzavejúcich ocelí. (Pitting corrosion of stainless steels.) 2009, Žilina, EDIS - Žilinská univerzita, 67.

[5] Ladwein, T.L.; Sorg, M.; Schilling, S. Influencing the Functional Properties of Stainless Steels by Different Surface Treatments, Corrosion 2011, March 13 - 17, Houston, Texas.

[6] Hong, T.; Nagumo, M. Effect of surface roughness on early stages of pitting corrosion of Type 301 stainless steel, Corrosion Science 1997, 39 (9), 1665-1672. https://doi.org/10.1016/S0010-938X(97)00072-3

[7] Sasaki, K.; Burstein, G.T. The generation of surface roughness during slurry erosion-corrosion and its effect on the pitting potential, Corrosion Science 1996, 38 (12), 2111-2120. https://doi.org/10.1016/S0010-938X(96)00066-2

[8] Zuo, Y.; Wang, H.; Xiong, J. The aspect ratio of surface grooves and metastable pitting of stainless steel, Corrosion Science 2002, 44, 25-35. https://doi.org/10.1016/S0010-938X(01)00039-7

[9] Burstein, G.T.; Pistorius, P.C. Surface Roughness and the Metastable Pitting of Stainless Steel in Chloride Solutions, Corrosion 1995, 51(5), 380-385. https://doi.org/10.5006/1.3293603

[10] Vaňa, D. Porovnanie technologických možností plazmového a elektrochemického leštenia antikoróznych oceli v elektrolyte. (Comparison of plasma technology options and electrochemical polishing of stainless steels in electrolyte.) 2014, Materiálovotechnologická fakulta STU, Trnava, AlumniPress, 101.

[11] Han, Y.; Mei, J.; Peng, Q.; Han, E.H.; Ke, W. Effect of electropolishing on corrosion of Alloy 600 in high temperature water, Corrosion Science 2015, 98, 72-80. https://doi.org/10.1016/j.corsci.2015.05.026

[12] Rokosz, K., Hryniewicz, T., Raaen, S., Valiček, J. SEM/EDX, XPS, corrosion and surface roughness characterization of AISI 316L SS after electrochemical treatment in concentrated HNO3, Tehnički vjesnik 2015, 22(1), 125-131. doi:10.17559/TV-20140211130812

[13] A. Pardo, A.; Merino, M.C.; Coy, A.E.; Viejo, F.; Carboneras, M.; Arrabal, R. Influence of Ti, C and N concentration on the intergranular corrosion behavior of AISI 316Ti and 321 stainless steels, Acta Materialia 2007, 55, 2239-2251. https://doi.org/10.1016/j.actamat.2006.11.021

[14] Hadzima, B.; Liptáková, T. Základy elektrochemickej korózie kovov 2008, Žilina, EDIS - Žilinská univerzita, 114. 
[15] Ziemniak, S.E.; Hanson, M.; Sander, P.C. Electropolishing effects on corrosion behavior of 304 stainless steel in high temperature, hydrogenated water, Corrosion Science 2008, 50, 2465-2477. https://doi.org/10.1016/j.corsci.2008.06.032

[16] Lee H.S.; Lai, J.J. The effects of electropolishing (EP) process parameters on corrosion resistance of AISI 316L stainless steel, J. Mater. Process. Technol. 2003, 140, 206-210. https://doi.org/10.1016/S0924-0136(03)00785-4

[17] Marek, P.; Dománková, M. Medzikryštalová korózia vybraných nehrdzavejúcich austenitických ocelí 2006, Katedra materiálového inžinierstva, MtF STU, Trnava.

[18] Chen, Q.; Thouas, G.A. Metallic implant biomaterials 2015, Materials Science and Engineering R, 87, 57. https://doi.org/10.1016/j.mser.2014.10.001

Submitted: $\quad 06.12 .2016$

Accepted: $\quad 28.6 .2017$
Viera Zatkalíková

viera.zatkalikova@fstroj.uniza.sk

Monika Oravcová

Peter Palček

Lenka Markovičová

Department of Material Engineering

Faculty of Mechanical Engineering

University of Žilina

Univerzitná 1

01026 Žilina 